\title{
A new genus and species of the spider family Linyphiidae (Aranei) from Israel
}

\author{
Новые род и вид пауков семейства Linyphiidae (Aranei) \\ из Израиля
}

\section{Andrei V. Tanasevitch \\ A.B. Танасевич}

\begin{abstract}
A.N. Severtsov Institute of Ecology and Evolution, Russian Academy of Sciences, Leninsky prospekt 33, Moscow 119071, Russia. E-mail: tanasevitch@gmail.com

Институт проблем экологии и эволюции им. А.Н. Северцова РАН, Ленинский проспект 33, Москва 119071, Россия.
\end{abstract}

KEY WORDS: taxonomy, Arachnida, Middle East, Levant.

КЛЮЧЕВЫЕ СЛОВА: таксономия, паукообразные, Ближний Восток, Левант.

ABSTRACT. A new erigonine genus, Protosintula gen.n., is described based on the type species Protosintula tenebrosus sp.n. from Israel. The genus seems to be especially similar to the genus Sintula Simon, 1884, but differs by the unmodified cymbium and a peculiar leg chaetotaxy pattern.

How to cite this paper: Tanasevitch A.V. 2021. A new genus and species of the spider family Linyphiidae (Aranei) from Israel // Arthropoda Selecta. Vol.30. No.4. P.573-576. doi: 10.15298/arthsel.30.4.14

РЕЗЮМЕ. Новый род Protosintula gen.n. с типовым видом Protosintula tenebrosus sp.n. описаны из Израиля. Род наиболее близок к Sintula Simon, 1884 от которого отличается немодифицированным цимбиумом и хетотаксией.

\section{Introduction}

The linyphiid fauna of Israel is presently known to comprise at least 47 species, of which about half stem from that country [Pickard-Cambridge, 1872; Pluess et al., 2008; Tanasevitch, 2011, 2013, 2020; Zonstein, Marusik, 2013; Zonstein et al., 2015].

A small spider material collected during a brief trip across Israel in 2011 (see Tanasevitch [2013]) contained a few unidentified species. One of these represented by a single male was provisionally determined as being close to the genus Sintula Simon, 1884. However, a closer study showed this similarity to have only been based on the structure of the embolic division, whereas other characteristic features in the male palp of Sintula, such as a highly modified cymbium with proximal process(es) and various formations like setae, outgrowth(s), teeth, etc., were all absent. This has prompted me to establish a new genus for that species alone, which undeniably does resemble Sintula.

The small erigonine genus Sintula is currently known to encompass 17 accepted species mostly confined to the Mediterranean realm (North Africa, Macaronesia, Iberian Peninsula, Austria, France, Balkan Peninsula, Ukraine, Caucasus, Near East). The type species is $S$. corniger (Blackwall, 1856), recorded from Europe, Turkey and the Caucasus [World Spider Catalog, 2021].

\section{Material and methods}

The holotype is kept in the Zoological Museum of the Moscow State University, Moscow, Russia (ZMMU. The holotype is preserved in $70 \%$ ethanol and has been studied using a MBS-9 stereo microscope. A Levenhuk C-800 digital camera was applied for taking some pictures. The sequence of leg segment measurements is as follows: femur + patella + tibia + metatarsus + tarsus. All measurements are given in millimeters. The chaetotaxy is given in a formula, e.g., TiI: 2-1-1-0, which means that tibia I has two dorsal spines, one pro-, one retrolateral spine, and no ventral spines (the apical spines are disregarded). Scale bars in the figures correspond to $0.1 \mathrm{~mm}$ unless indicated otherwise. Figure numbers are shown above the scale bars. The terminology concerning the structure of the copulatory organs mainly follows that of Merrett [1963], as well as those of the authors mentioned in the Abbreviations section below.

The following abbreviations are used in the text and figures: Co — column sensu Saaristo [1971], D — duct, DSA - distal suprategular apophysis sensu Hormiga [2000], EP - embolus proper sensu Saaristo [1971], Fe - femur, MM - median membrane sensu Helsdingen [1965], Mt metatarsus, $\mathrm{R}$ - radix, $\mathrm{T}$ - tegulum, Ti - tibia, TmI position of a trichobothrium on metatarsus I.

Order Aranei Clerck, 1758

Family Linyphiidae Blackwall, 1859

Subfamily Erigoninae Emerton, 1882

\section{Protosintula gen.n.}

TYPE SPECIES: Protosintula tenebrosus sp.n.

NAME. The generic name is a combination of two words, "proto" and Sintula, meaning "primary" and related to Sin- 

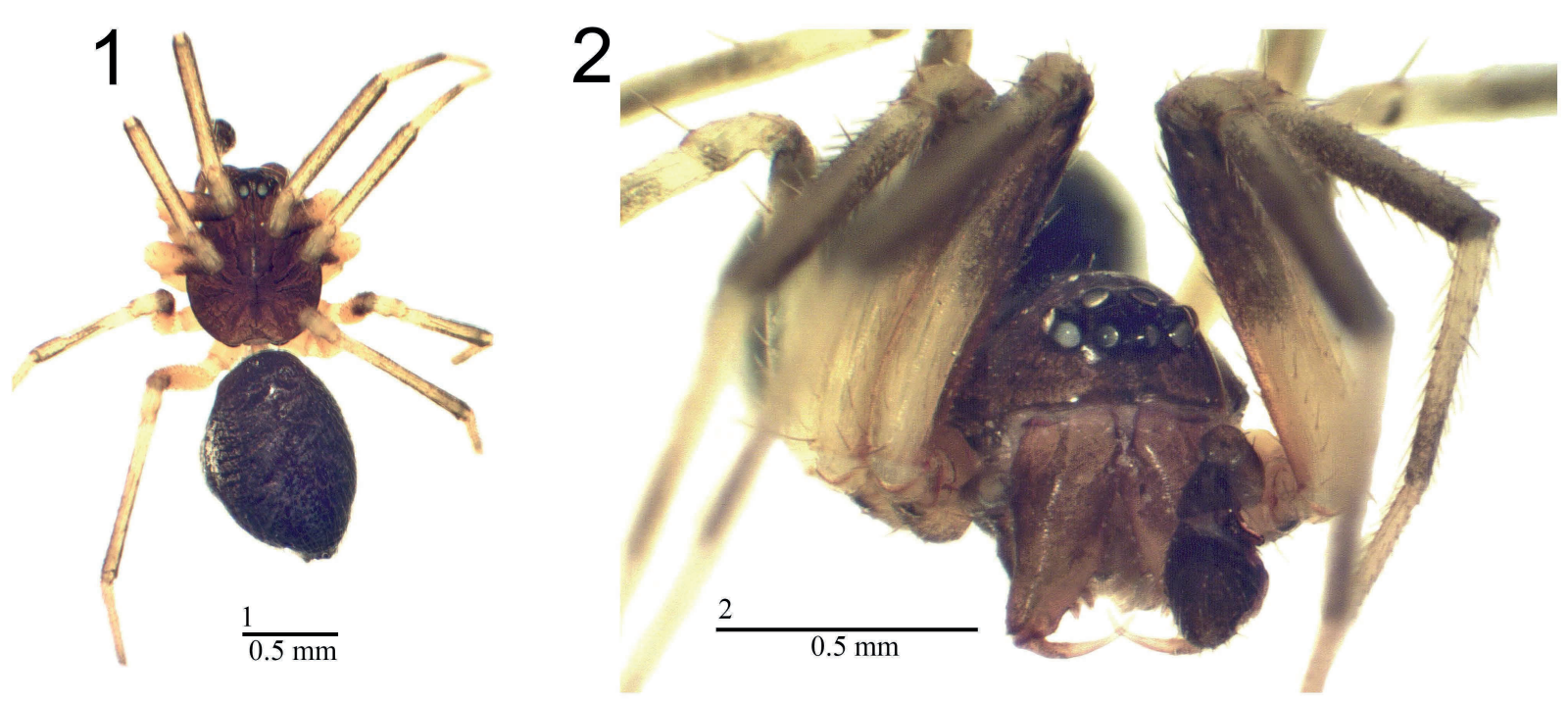

Figs 1-2. Protosintula tenebrosus sp.n., $\sigma^{7}$ holotype. 1 - habitus, dorsal view; 2 - prosoma, frontal view.

Рис. 1-2. Protosintula tenebrosus sp.n., о голотип. 1 - внешний вид сверху; 2 - головогрудь спереди.

tula, but showing a much more simple male palp. The gender is masculine.

DIAGNOSIS. The new genus of Erigoninae is diagnosed by the peculiar chaetotaxy, an unmodified cymbium, as well as the compact, poorly sclerotized embolic division with a very short embolus.

DESCRIPTION. See description of the type species.

TAXONOMIC REMARKS. Based on the structure of the embolic division, namely, the compact, poorly sclerotized embolic division with a very short embolus, as well as the presence of a dorsal spine each on metatarsi I-II, the new genus seems to be especially similar to Sintula Simon, 1884. Protosintula gen.n. differs by the unmodified cymbium, i.e., the absence of peculiar posterodorsal cymbial process(es) furnished with setae, teeth, apophyses, etc. Protosintula gen.n. is also distinguished from Sintula by the leg dorsal spine formula, i.e., 2.2.2.1 vs 2.2.1.1.

SPECIES INCLUDED. Only the type species.

DISTRIBUTION. Known only from Israel.

\section{Protosintula tenebrosus sp.n.}

Figs 1-9.

HOLOTYPE $\sigma^{7}$ (ZMMU), ISRAEL, Central Negev Desert, Sede Boqer $\left(30.848598^{\circ} \mathrm{N}, 34.778367^{\circ} \mathrm{E}\right)$, under stone near building, by hand, 5.X.2011, leg. A. Tanasevitch.

NAME. The species epithet is a Latin adjective meaning "dark", referring to the body colour.

DESCRIPTION. Male holotype. Total length 2.20. Carapace unmodified, 1.03 long, 0.75 wide, blackish brown, with vague, grey, radial stripes (Fig 1). Chelicerae unmodified, 0.45 long, promargin of each with two large tooth, retromargin with one or two small teeth (Fig. 2). Legs yellow, with dark longitudinal stripes and infuscate ends of leg segments. Leg I, 3.16 long $(0.88+0.30+0.80+0.68+$ $0.50)$, IV, 3.36 long $(0.93+0.25+0.93+0.80+0.45)$. Chaetotaxy: FeI-IV spineless; TiI-II: 2-0-1-0, TiIII: 2-0-00, TiIV: 1-0-0-0; MtI-II: 1-0-0-0, MtIII-IV spineless. Spines $1-1.5 \mathrm{x}$ as long as diameter of corresponding leg segment. TmI, 0.32. Metatarsi IV without trichobothria. Palp (Figs 39): patella slightly elongated, dorsally terminating in a weak spine. Tibia black, unmodified. Cymbium black, with a small, rounded, posterodorsal convexity. Paracymbium L-shaped, with a poorly expressed projection on its posterior side. Tegulum with a wrinkled surface in protegulum area. Distal suprategular apophysis long, narrow, regularly curved, with a triangular outgrowth near middle. A median membrane present, short. Embolic division bean-shaped, compact, poorly-sclerotized, its external lobe serrate. Embolus a very short needle. Abdomen (Fig. 1) 1.23 long, 0.75 wide, almost black.

Female unknown.

TAXONOMIC REMARKS. See above.

DISTRIBUTION. Known only from Israel.

Acknowledgements. I am most grateful to Sergei Golovatch (Moscow) for editing an advanced draft of the manuscript. This study was supported in part by the Presidium of the Russian Academy of Sciences, Program No. 41 "Biodiversity of natural systems and biological resources of Russia".

\section{References}

Helsdingen P.J. van. 1965. Sexual behaviour of Lepthyphantes leprosus (Ohlert) (Araneida, Linyphiidae), with notes on the function of the genital organs // Zoologische Mededelingen. Vol.41. P.15-42.

Hormiga G. 2000. Higher level phylogenetics of erigonine spiders (Araneae, Linyphiidae, Erigoninae) // Smithsonian Contributions to Zoology. No.609. P.1-160.

Merrett P. 1963. The palpus of male spiders of the family Linyphiidae // Proceedings of the Zoological Society of London. Vol.140. P.347-467.

Pickard-Cambridge O. 1872. General list of the spiders of Palestine and Syria, with descriptions of numerous new species, and characters of two new genera // Proceedings of the Zoological Society of London. 1871. P.212-354.

Pluess T., Opatovsky I., Gavish-Regev E., Lubin Y., Schmidt M.H. 2008. Spiders in wheat fields and semi-desert in the Negev (Israel) // Journal of Arachnology. Vol.36. No.2. P.368-373.

Saaristo M.I. 1971. Revision of the genus Maro O. P.-Cambridge (Araneae, Linyphiidae) // Annales Zoologici Fennici. Vol.8. P.463-482. 


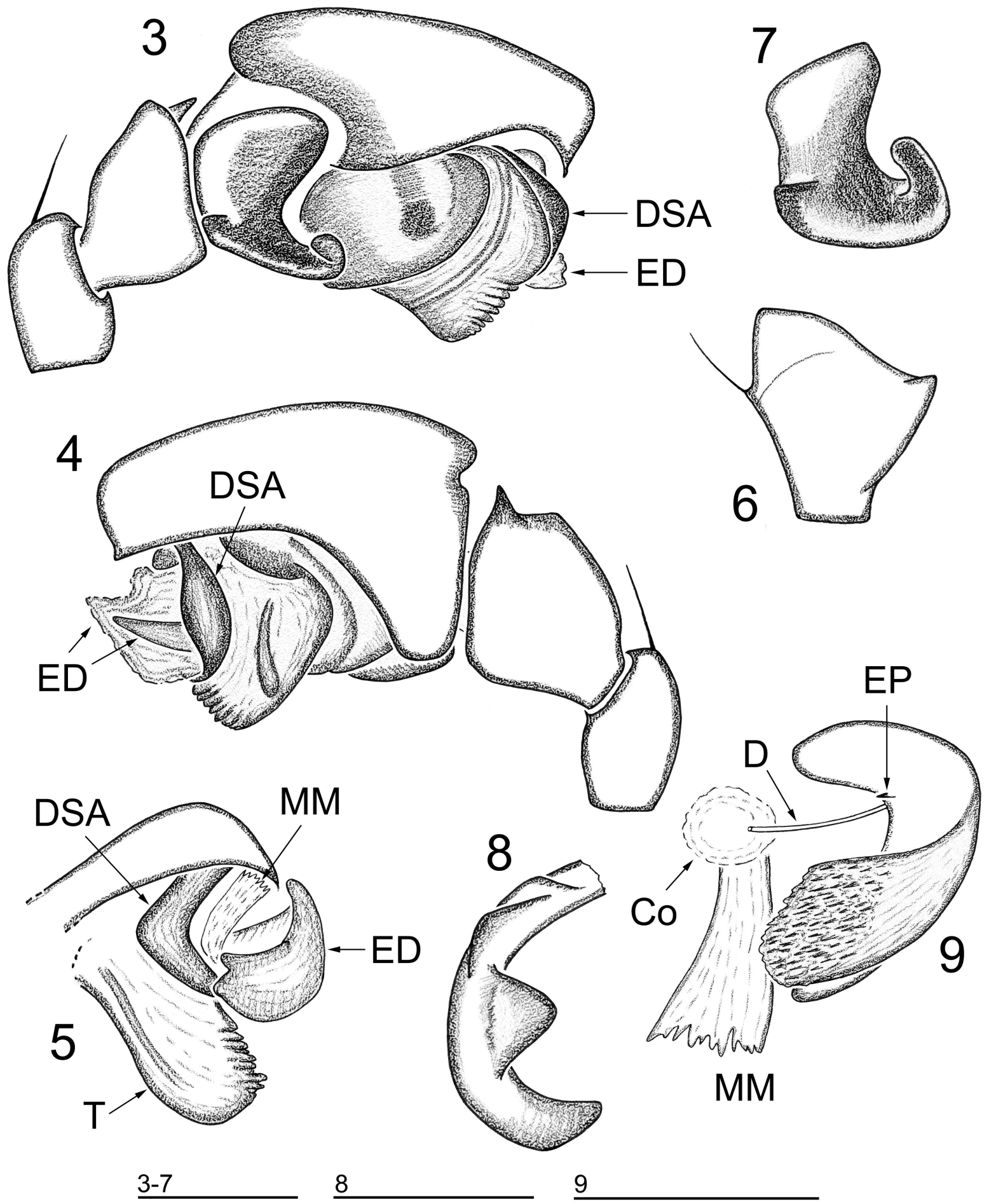

Figs 3-9. Details of male palpal structure of Protosintula tenebrosus sp.n., holotype. 3-4 - right palp, retrolateral and prolateral view, respectively; 5 - distal part of palp, prolateral view; 6 - palpal tibia, dorsal view; 7 - paracymbium; 8 - distal suprategular apophysis; 9 - embolic division and median membrane, ventro-prolateral view.

Рис. 3-9. Детали строения пальпы самца Protosintula tenebrosus sp.n., голотип. 3-4 - правая пальпа соответственно ретролатерально и пролатерально; 5 - дистальная часть пальпы пролатерально; 6 - голень пальпы сверху; 7 - парацимбиум; 8 дистальный отросток супратегулюма; 9 - эмболюсный отдел и медиальная мембрана пролатерально и снизу. 
Tanasevitch A.V. 2011. On linyphiid spiders (Araneae) from the Eastern and Central Mediterranean kept at the Museum d'histoire naturelle, Geneva // Revue suisse de Zoologie. T.118. Fasc.1. P.49-91.

Tanasevitch A.V. 2013. On linyphiid spiders (Araneae) from Israel // Revue suisse de Zoologie. T.120. Fasc.1. P.101-124.

Tanasevitch A.V. 2020. A new species of the genus Theonina Simon from Israel (Aranei: Linyphiidae) // Arthropoda Selecta. Vol.29. No.3. P.367-370.
Zonstein S.L., Marusik Yu.M., Omelko M.M. 2015. A survey of spider taxa new to Israel (Arachnida: Araneae) // Zoology in the Middle East. Vol.61. No.4. P.372-385.

Zonstein S.L., Marusik Yu.M. 2013. Checklist of the spiders (Araneae) of Israel // Zootaxa. Vol.3671. No.1. P.1-127.

World Spider Catalog 2021. World Spider Catalog, version 22.0

Natural History Museum Bern. Online at http://wsc.nmbe.ch (accessed in June, 2020).

Responsible editor K.G. Mikhailov 